\title{
WALT WHITMAN AND THE KING OF BOHEMIA: THE POET IN THE SATURDAY PRESS
}

\author{
AmANDA Gailey
}

AFTER THE DISAPPOINTING RECEPTION OF THE SECOND EDITION of Leaves of Grass in 1856, Walt Whitman began deepening his connections with the New York art crowd and became a regular at Pfaff's beer cellar, notorious for its unconventional and rowdy clientele. The years 1856 to 1860 , between the publications of the second and third editions of Leaves, have often been regarded as anomalous in Walt Whitman's long poetic career, and, since Whitman kept relatively little record of them, have lent themselves to both speculation and neglect. Although inadequately documented, these years were important ones, and Whitman clearly wrote a great deal of poetry during this time. He added almost 150 new poems in the third edition, causing the number of poems in Leaves to increase by more than fivefold. Significantly, it was during this period that a commercial publisher first agreed to publish the book at no cost to Whitman. This milestone in Whitman's career-when he was hoisted into the world of professional authorship - was enabled by Whitman's complex, symbiotic relationship with a New York newspaper editor, Henry Clapp, Jr., whose interest in Whitman attracted the attention of the abolitionist Boston publishing firm Thayer and Eldridge. In turn, Whitman's association with these publishers on the eve of the Civil War transformed him, in the eyes of the reading public, into a distinctly factional, Northern poet.

By tracing the events that led to the 1860 publication of Leaves of Grass, we discover that Whitman's national reputation was first shaped by a series of barters. To secure his place in the pages of a prominent New York newspaper, Whitman agreed to weather whatever commentary - from abuse to praise - its editor sent in his direction. To leverage this exposure into a published book, this inclusive poet of "Yankee, Georgian, native, immigrant, sailors, squatters, old States, new States" was publicly cast as a keenly factional, Northern voice. ${ }^{1}$ Years later, he would reflect on this period to his friend Horace Traubel: "Henry [Clapp] was right: better to have people stirred against you if they can't be stirred for you-better that than not to stir them at all. I think I first thrived on opposition: the allies came later." 2 As the nation approached 
war, Whitman, because of his relationships with Clapp and Thayer and Eldridge, found himself steeped in opposition: not the poet of a diverse yet cohesive union, but the public symbol of the most radical and alienating aspects of Yankee politics and aesthetics.

In 1858 Whitman met Henry Clapp, Jr., who, like the poet, was a former temperance writer turned carousing bohemian. It was Clapp, in fact, who imported "bohemianism" from Paris, earning him the moniker "King of Bohemia." The men had much in common: they were older than most of the other bohemians who frequented Pfaff's; they were interested in exploring alternatives to male-female monogamy; they both had Quaker roots but unorthodox religious beliefs; and they both felt trepidation about the looming war. ${ }^{3}$ As David Reynolds has noted, the late 1850 s were a critical time for New York bohemians as they sought to evade real engagement with the national crisis by hiding behind a contrived and nihilistic individualism that "had sunk toward anarchic decadence." "War was only getting closer, and the bohemians were soon to learn that any movement that neglected this somber fact would find itself irrelevant once the nation faced violence and loss.

On the eve of national disaster, Clapp founded the ill-fated Saturday Press, which, though under-funded and short-lived, achieved prestige among Northern literary circles. ${ }^{5}$ The sheer quantity of poems, parodies, homages, reviews, and essays concerning Whitman that were either first published or reprinted in the Saturday Press is astounding: in the single year between Whitman's first publication in the Press, "A Child's Reminiscence," and the paper's closure in December 1860, Clapp printed or reprinted from other newspapers no fewer than 46 items-excluding advertisements - by or about Walt Whitman. Virtually all of these Whitman-related pieces in the Press offer illuminating glimpses into the making of a literary career, and serve as a record of how the reading public responded to Whitman's controversial poems as he transitioned visibly into the role of vocational poet. ${ }^{6}$ Indeed, Whitman, throughout his life, was cognizant of how this exposure influenced his early career, and decades later he said to Horace Traubel, "I've always told you it is essential for you to know about Henry Clapp if you want to really know me: he was one of the earlier fellows: he was literary but he was not shackled (except by debts): he gave me more than one lift: contended for me against odds" (WWC 4:195). The Saturday Press is a complex testimony to Clapp's dedication to Whitman. This essay will focus on those pieces in the Press that were most significant to molding Whitman, just before the Civil War, into a factional poet of the North. ${ }^{7}$

In the December 24, 1859, issue of the Saturday Press, Whitman published "A Child's Reminiscence" (later "Out of the Cradle Endlessly Rocking"). In this first venture between Whitman and Clapp-also Whitman's first poetic publication since the 1856 edition - the poet and 


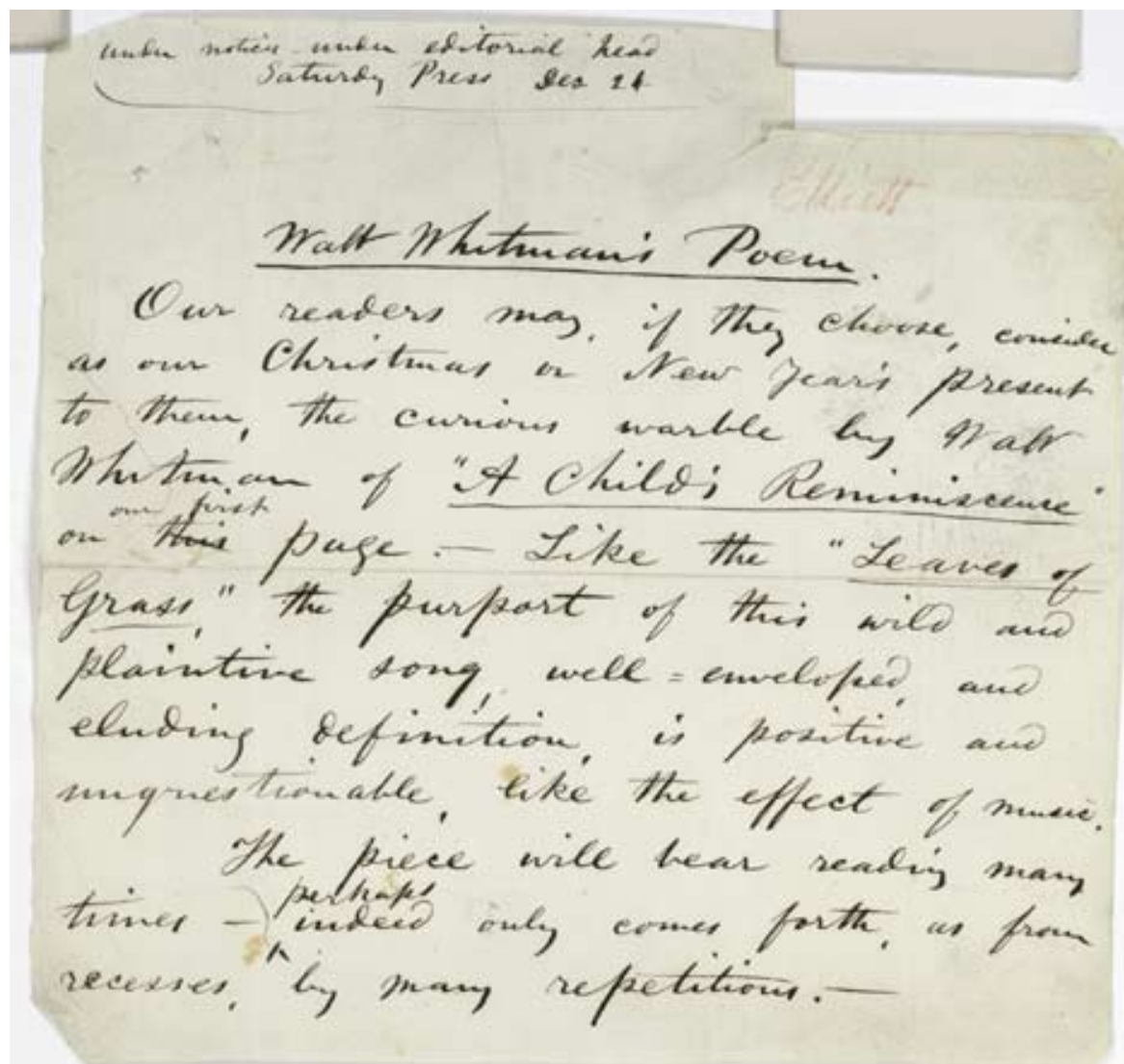

Figure 1. Draft of editorial note for Saturday Press. The Henry W. and Albert A. Berg Collection of English and American Literature, New York Public Library.

publisher set a pattern for their dealings over the next year. Clapp was a staunch supporter of Whitman and viewed the relationship between the paper and the poet as symbiotic: he would work to attract attention of any variety to Whitman, which, as this attention grew, would in turn attract readers to the paper that so frequently spotlighted the poet. Clapp's active participation in Whitman's public image began with the publication of "A Child's Reminiscence," not just through his acceptance of the poem, but also through a note in the same issue, encouraging readers to thoughtfully consider the poem:

\section{WALT WHITMAN'S POEM.}

Our readers may, if they choose, consider as our Christmas or New Year's present to them, the curious warble, by Walt Whitman, of " $A$ Child's Reminiscence," on our First Page. Like the "Leaves of Grass," the purport of this wild and plaintive song, 
well-enveloped, and eluding definition, is positive and unquestionable, like the effect of music.

The poem will bear reading many times_-perhaps, indeed, only comes forth, as from recesses, by many repetitions.

Although the note appears to readers to have been written by Clapp, it was, in fact, drafted by Whitman, as a manuscript in his hand at the New York Public Library shows (see Figure 1), and was printed wholesale by Clapp on the editorial page.

Whitman had written advertisements for "A Child's Reminiscence" to be sent to several newspapers. One that he sent to the New York Times, the New York Sun, the New York Tribune, and the New York Evening Post simply contained the text he wanted the papers to include (see Figure 2). The Times omitted Whitman's wording, which included the heading "a beautiful work of art," and substituted their own text in their "Literary and Art Items":

Walt Whitman, the author of Leaves of Grass who shot up to the literary heavens so suddenly three years ago, and sent "his barbaric yawp over the roofs of the world," seems to be once more rousing himself to speech, and "shoots his voice high and clear over the waves" in the Saturday Press of to-day with a new and characteristic poem entitled "A Child's Reminiscence."

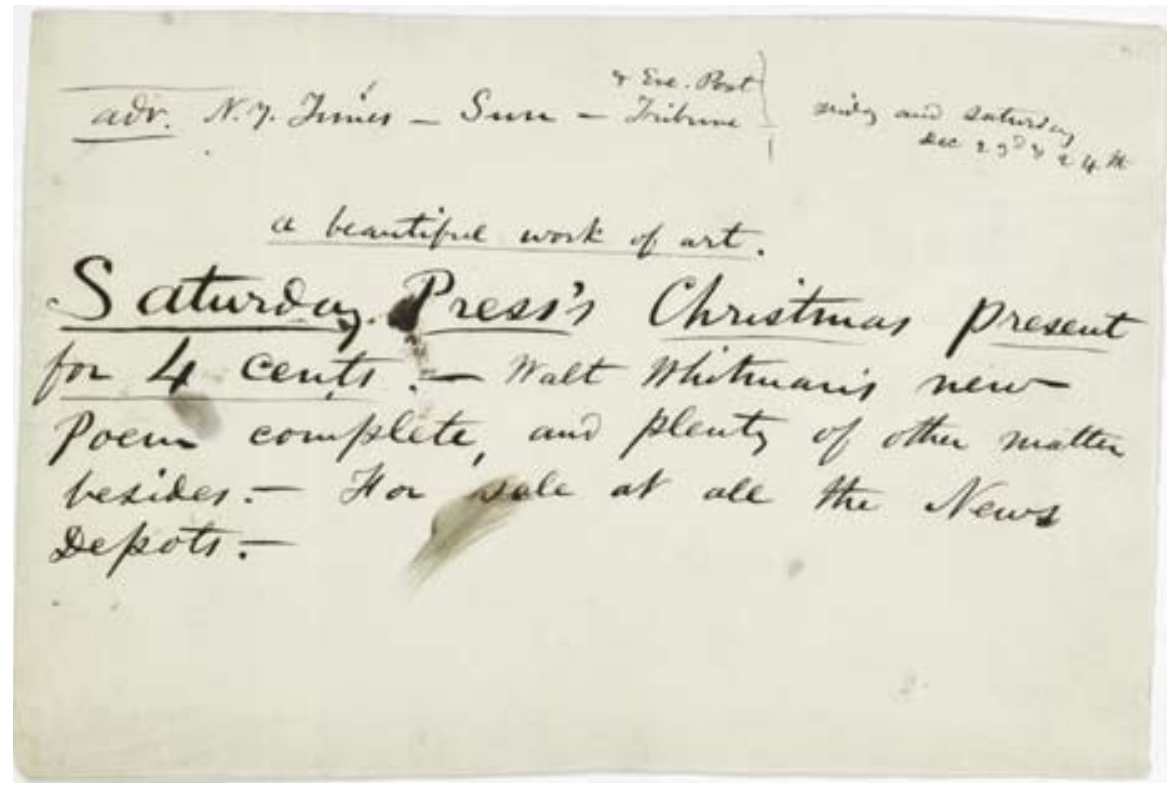

Figure 2. Draft of advertisement for New York newspapers. The Henry W. and Albert A. Berg Collection of English and American Literature, New York Public Library. 


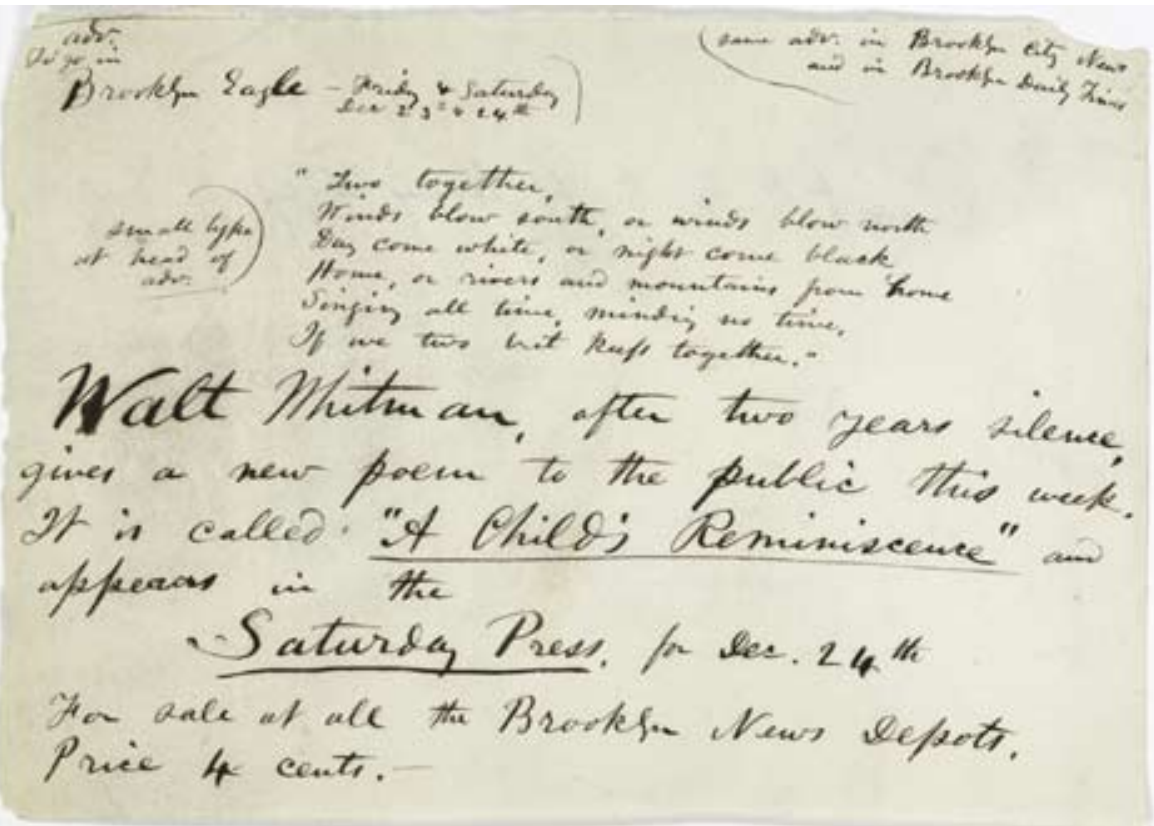

Figure 3. Draft of advertisement for the Brooklyn Eagle. The Henry W. and Albert A. Berg Collection of English and American Literature, New York Public Library.

Whitman's draft of a notice for a different paper, the Brooklyn Eagle, included directions to the printer for how to display the text (see Figure 3). Similarly, his draft of the notice that Clapp would print in the Press specifies that it was to appear "under notices-under editorial head." These instructions indicate Whitman knew that his personal connections to these papers would mean that the advertisements would run as he desired. However, the advertisement that he sent to the Times lacked such instructions because he knew that the notice would be published at their discretion, and that they would not follow such specifications from him. He was, with Clapp's cooperation, heavy-handedly guiding his publicity in the newspapers that he could influence while at the same time seeding newspapers beyond his control. Clapp clearly would have supported this media orchestration since he sought readers for the Press. (In fact, if the Times were to have used Whitman's wording, the Press would have been even more strongly advertised, since Whitman mentions that the issue contained "plenty of other matter besides.") The Times's notice shows that the Clapp/Whitman alliance was working from the outset: as soon as Whitman began his association with the Press, both poet and editor were attracting attention.

The complement of Whitman's poem on the first page of the Press with the enthusiastic "editorial" comment on the inside of the paper 
would set the pattern for the paper's dealings with Whitman over the next year, during which the poet's own writing would frequently be set against responses or implied endorsements by others. Two weeks later, on January 7, Clapp included on the front page a damning review of the poem from the Cincinnati Commercial, which inadvertently praised the Press even as it condemned the poet who "soil[ed] the spotless white of its fair columns with lines of stupid and meaningless twaddle." To counter the Commercial's criticism, Clapp printed an anonymous review, "All About a Mocking-Bird," which was, unsurprisingly, authored by Whitman. Even a public unaware of Whitman's and Clapp's marketing tactics could probably have deduced that Whitman was behind the effusive review. Not only did it contain several characteristic exclamations, it also imparted an insider's knowledge of Whitman's plans:

We are able to declare that there will also soon crop out the true "LEAVES OF GRASS," the fuller-grown work of which the former two issues were the inchoatesthis forthcoming one, far, very far ahead of them in quality, quantity, and in supple lyric exuberance.

Whitman further explains that the first two "issues" were "little pittance-editions, on trial" and that the nation needs to be supplied with "copious thousands of copies." This optimism is particularly striking given that, in January 1860, Whitman did not even have the support of publishers willing to back the book financially. It seems that Whitman was gambling on this very venue, the Saturday Press, to help him bring these claims to fruition.

Accounts of the poet's dealings with Thayer and Eldridge usually speculate that the firm contacted Whitman in February of 1860 because they had just learned that Fowler and Wells had abandoned him. Recently, Albert J. Von Frank has complicated this theory by hypothesizing that one of Thayer and Eldridge's authors, Richard Hinton, had viewed John Brown's body in New York and concluded that it looked just like Walt Whitman:

Undoubtedly Hinton told this story when he got back to Boston and no doubt also explained that he had first met Whitman in $1855 \ldots$ hearing these stories evidently revived in Thayer and Eldridge a recollection of their own strongly positive reaction to the poems in 1855, when, indeed, they had seemed to find their most receptive audience among transcendentalists, Bohemians, and reformers. Flush with income ... Thayer wrote to Whitman in early February . . . and declared their desire to "be known as the publishers of Walt. Whitman's books, and [to] put our name as such under his, on title-pages." 8 
It is quite possible that Thayer and Eldridge would have found Whitman's supposed resemblance to John Brown compelling; nevertheless, it is likely that something more immediate than a physical resemblance or a five-year-old memory of liking his poems motivated them to publish his book. It seems especially unlikely that such flimsy reasons would have prompted the firm to contact Whitman, given that Fowler and Wells - who did not even pay to publish the 1856 edition of Leaves - had found Whitman too risky a client to sustain. In fact, the 1856 edition had languished on the shelves for four years at that point, which could not have been a factor in Whitman's favor. However, as Von Frank later argues, Thayer and Eldridge were also actively cultivating authors who would appeal to bohemians, as evidenced by their interest in William Douglas O'Connor. In the two months before the publishers contacted Whitman, he had published four poems in the Saturday Press-a fact that would have made publishers who courted a bohemian audience take notice. Furthermore, the frequency of these new poems likely signaled to Thayer and Eldridge that Whitman was on the verge of publishing a new book.

On March 15, 1860, Whitman arrived in Boston to oversee the production of Leaves of Grass. ${ }^{9}$ Ezra Greenspan has noted the rather complex relationship forged among Whitman, Clapp, and Thayer and Eldridge, in which Whitman played the unfortunate go-between, trying to broker advertising revenue from the publishing firm for the increasingly desperate editor. ${ }^{10}$ Eventually the arrangement fell apart, which perhaps contributed to Clapp's and Whitman's ultimate estrangement, but for some time Clapp's paper was actively promoting Whitman's book for many reasons: friendship, a desire to boost readership, and advertising revenue. The almost eight months in which this advertising campaign flourished deserve closer attention, and illuminate an important means by which Whitman was constructed as a distinctively Northern figure in the year before the war.

In March, while Whitman was in Boston preparing the third edition, Clapp wrote to him alerting him to the announcement of the forthcoming book that had run in the Press the previous week, and reminding him to "let me know about when the book is to be ready. I can do a great deal for it" ( $W W C 1: 236$ ). He then suggests to Whitman that if Thayer and Eldridge move quickly they should be able to cash in on the publicity Whitman had gained through his recent publication of "Bardic Symbols" in the Atlantic Monthly. Coyly, he hints to Whitman that the Saturday Press may be the right venue for a full-fledged advertising campaign just before he frankly admits that he is in dire straits: 
.. . The papers all over the land have noticed your poem in the Atlantic and have generally pitched into it strong; which I take to be good for you and your new publishers, who if they move rapidly and concentrate their forces will make a Napoleonic thing of it.

It just occurs to me that you might get Messrs. T. \& E. to do a good thing for me: to wit, advance me say one hundred dollars on advertising account - that is if they mean to advertise with me. Or if they don't to let me act for them here as a kind of N.Y. agent to push the book, and advance me the money on that score.

I must have one hundred dollars before Saturday night or be in a scrape the horror of which keeps me awake o' nights. I could if necessary give my note at three mos. for the amount and it is a good note since we have never been protested. (WWC 1:237)

Clapp's plea for help from the publishing house was successful. Between April 21, 1860, and December 8, 1860, Thayer and Eldridge ran sixteen different advertisements in the Saturday Press, each appearing anywhere from one to ten times. Nine of these advertised Leaves of Grass alone, one advertised Leaves of Grass along with other Thayer and Eldridge publications, and six advertised other Thayer and Eldridge publications not including Leaves of Grass. All together, there were twenty-nine appearances of advertisements for Leaves of Grass alone; six for Thayer and Eldridge publications including Leaves of Grass, and ten for Thayer and Eldridge publications other than Leaves of Grass. All told, then, Thayer and Eldridge advertised Leaves of Grass in Henry Clapp's paper thirty-five times over the course of thirty-three weeks.

The advertising campaign was a mutually beneficial collaboration among Clapp, the publishing firm, and Whitman, and it served to significantly boost the poet's already considerable visibility in the newspaper. In the fifty-one weeks from the publication of "A Child's Reminiscence," his first appearance in the pre-war run of the Press, to "A Portrait," his last, there were-counting advertisements-no fewer than seventy-two Whitman-related items in the newspaper.

Thayer and Eldridge advertised their books actively, to be sure, but their almost constant presence in the Press for these eight months far exceeded their advertising efforts in other publications. The Boston Daily Evening Transcript published small Thayer and Eldridge ads fairly frequently during this time, but ran only two ads for Leaves, and these fewer than a dozen times. Neither ad compared to the stunning elaborateness of such appearances in the Press as one beginning with a quote from "A Woman" (actually Juliette Beach), which packed endorsements of the book into a column that ran approximately twenty inches long. Thayer and Eldridge were much more visible within the pages of the Liberator, William Lloyd Garrison's weekly abolitionist paper also published in Boston. Here, though, where the firm clearly found one of their target audiences, their ads focused almost entirely on their overtly 
abolitionist texts. Their advertisements for James Redpath's Life of Captain fohn Brown even appealed to readers by announcing that a portion of the book's profits would go to Brown's family - a gambit that they did not even attempt in papers that catered to more general Northern audiences that were potentially more squeamish. Most of their ads in the Liberator do not even mention Whitman; the one that does, which ran in October and November of 1860, gives Whitman only the bottom three lines of a sixty-three-line advertisement.

On March 24, 1860, the Press began running short notices of the forthcoming Leaves of Grass, but the first Thayer and Eldridge ad that ran in the Press included no mention of Whitman (see Figure 4), even though he was at the time-April 2-at work with the publishers in Boston. Instead, the ad publicized four staunchly abolitionist works: Echoes of Harper's Ferry by Redpath, which Thayer and Eldridge was just releasing; a recently published pamphlet titled "The Thrilling Narrative of Dr. John Doy, of Kansas; Or, Slavery as it Is-Inside and Out"; Redpath's Life of Captain fohn Brown; and another forthcoming work by Redpath, Talks with the Slaves in the Southern States, which would become one of the only antebellum collections of its kind. The ad was highly political and in fact mentioned that Echoes was "valuable for circulation as a presidential campaign document." Such an ad would have helped establish a political context for Whitman's new edition by visibly and forcefully declaring the publisher's abolitionist mission within the newspaper that it would use as the primary venue to advertise Whitman's book. The next week the firm ran its first Leaves of Grass ad and, just two weeks later, was again advertising Echoes of Harper's Ferry (see Figure 5). Thayer and Eldridge's long campaign of interspersing publicity for Whitman's poetry among publicity for often militant abolitionist writings would have, in the eyes of readers, built a strong association between Whitman's new edition and the publishers' cause.

This first ad that Thayer and Eldridge placed in the Saturday Press would also begin an inappropriate use of Emerson that rivaled Whitman's brazen use of the now-famous letter on the spine of his 1856 edition, where he printed, without permission, Emerson's private comment, "I greet you at the beginning of a great career." The ad begins, "IN PRESS! AND TO BE ISSUED IMMEDIATELY: Echoes of Harper's Ferry." This notice is immediately followed by a quotation from Emerson's 1836 "Concord Hymn," concluding with the lines "Here once the embattled farmers stood, / And fired the shot heard round the world." The poem, of course, had been written about the American Revolution, but in this ad the publishers use it to describe the looming Civil War or at least to associate militant abolitionism with the patriotism of the Revolution. 


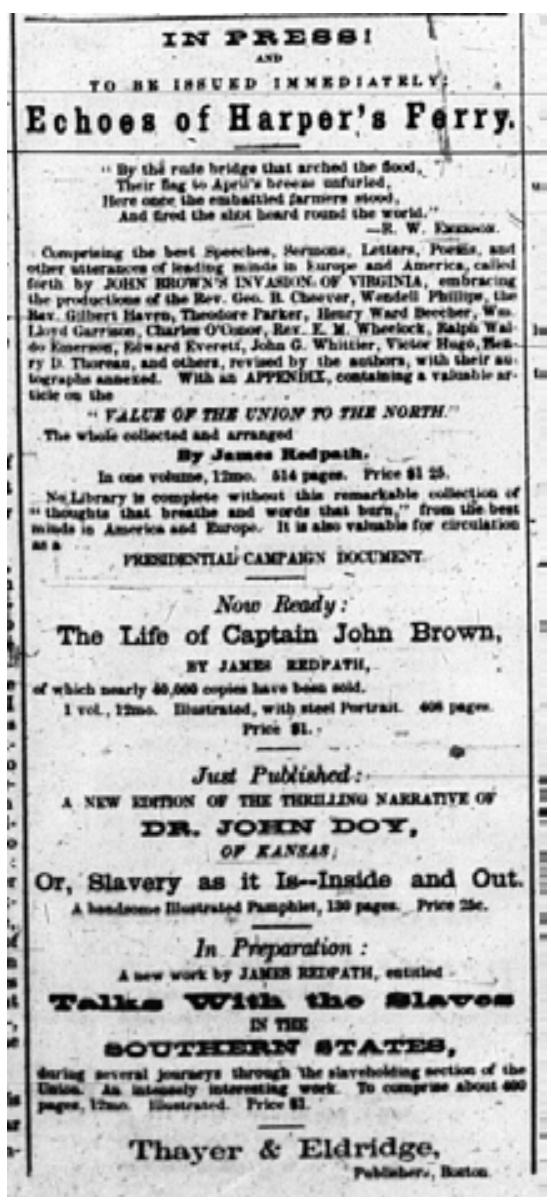

Figure 4. "IN PRESS!" Ran on April 21, 1860.

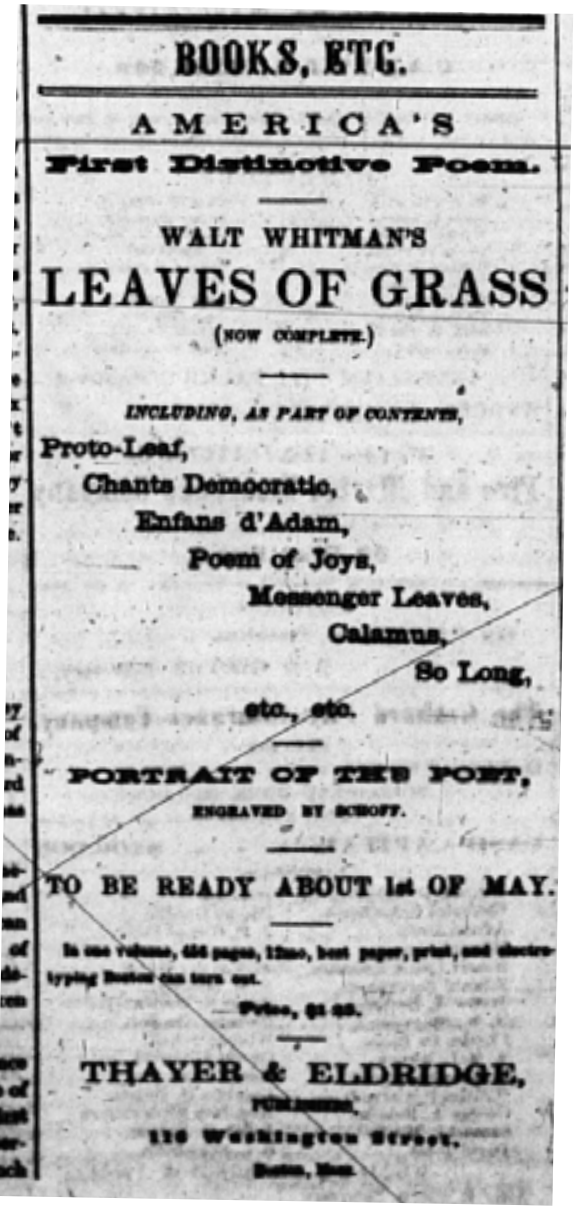

Figure 5. "AMERICA'S First Distinctive Poem." Ran on April 28, May 5, and May 12. It was not until May 12 that the ad changed the line "To be ready about $1^{\text {st }}$ of May."

In an advertisement that ran only once, on July 21 , Thayer and Eldridge would again put Emerson to work for them, this time by quoting his famous letter to Whitman:

\section{Emerson}

Pronounced the first issue of them-(and the present is twenty times more perfect, poetical, and voluminous) -

"The most extraordinary Piece of Wit and Wisdom that America has yet contributed." 
The very next week, Emerson was again prominently positioned in a Leaves of Grass ad (see Figure 6). After the header "America's First Distinctive Poem" was the quote "Incomparable things, said incomparably well." The use of this statement, which would appear in the Press eleven times in two different advertisements, was in especially bad form, given that Emerson had repeatedly urged Whitman to cut the scandalous "Enfans d'Adam" poems from the 1860 edition. Ted Genoways has recently noted that Whitman believed Emerson actually thought more highly of him for sticking to his guns and retaining the controversial poems - that Emerson had in fact objected on practical (not moral) grounds, fearing that the poems would impede circulation of Leaves. ${ }^{11}$ But even if Emerson had no quarrel with the poems' artistic merit, he surely would not have publicly recommended them. Nevertheless, beneath the Emerson quotation in this ad are listed the contents of the new Leaves, including, of course, "Enfans d'Adam," thus making the well-worked blurb look like an endorsement for the very poems that Emerson wanted expunged.

On the eve of Civil War, these Saturday Press ads, which mingle the names of Emerson, Whitman, and Thayer and Eldridge, serve as an unlikely intersection of Boston Brahmanism, New York bohemianism, and die-hard abolitionism. Whitman sought Emerson's approval to garner literary credibility, which Emerson expressly denied. Thayer and Eldridge likely wanted Emerson's endorsement for political credibility, which was out of place in an ad for their least abolitionist publication. Though Emerson's approval was poached and misplaced, it would

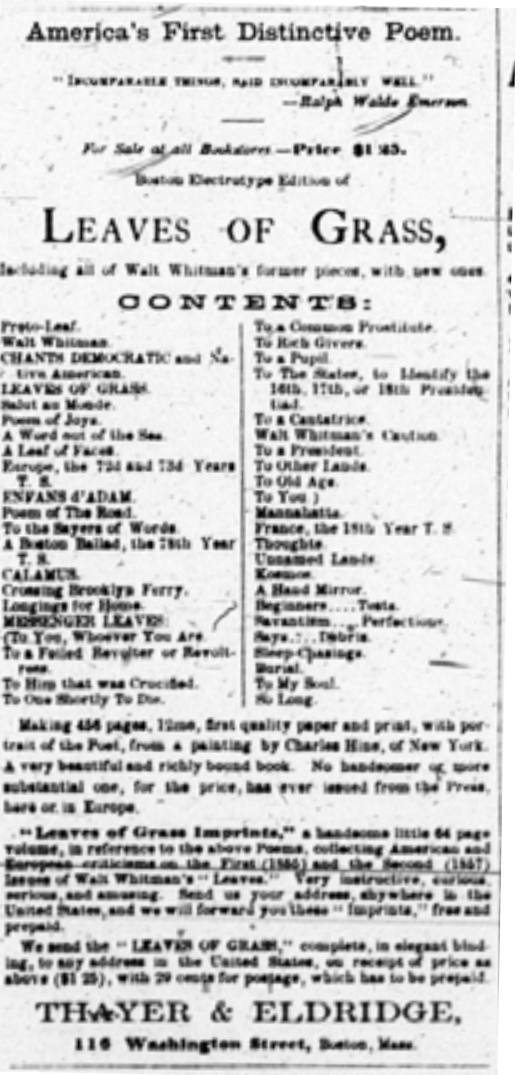

Figure 6. "America's First Distinctive Poem." Ran on July 28, August 4, August 11, August 18, and September 1. Ran on September 8, September 22 , and October 6 with the first line changed to "Poem of Democracy." Ran on October 27 and November 3 with the first line changed to "Poem of the New World." 
nevertheless confirm Southern suspicions about Whitman's status as a factional, "representative man of the North."

On May 19, shortly after the advertising campaign was launched and as Whitman's new edition was just being released, the Saturday Press published one of the most adulatory reviews of Leaves of Grassso adulatory, in fact, that scholars have disagreed about whether Clapp or Whitman authored it. Indeed, both Whitman and Clapp had such vested interests in the book at this point that the review's effusiveness could be attributed to either one of them. The review, one of the most well-known documentations of the contemporary reception of Leaves, begins: "We announce a great Philosopher-perhaps a great Poet-in every way an original man. It is Walt Whitman. The proof of his greatness is in his book; and there is proof enough." As testament to the collaboration that had evolved among Whitman, Clapp, and Thayer and Eldridge, the editorial concludes:

We should not conclude our notice of the Leaves of Grass without expressing our very great delight at the sumptuous elegance of the style in which Messrs. Thayer \& Eldridge have published Walt Whitman's poetry. The volume presents one of the richest specimens of taste and skill in book-making, that has ever been afforded to the public by either an English or an American publisher.

Even this review, supposedly the straightforward opinion of the editor or a contributor, was really a result of the complex, symbiotic alliance of poet, periodical, and publisher that was working to forge Whitman's place in American letters. While critics have seldom assigned definitive authorship of the review to either Whitman or Clapp, Clapp was almost certainly the review's author. Just one week earlier, Clapp wrote to Whitman renewing his commitment to help Whitman's career: "The publishers and printers deserve high praise for the superb manner in which they have done their work. For the poet, he shall hear from me next week" ( $W W C$ 4:195). The review in question appeared the next week. To confirm matters further, Clapp even echoed in the review his letter's praise of the publishers' workmanship.

Clapp prided himself on his objectivity and made his refusal to "puff" a recurring theme in the Saturday Press by repeatedly stressing his impartiality in his own editorials and in the praise he chose to reprint in the paper. Of course - as his treatment of Whitman demonstrateshis personal tastes in both poetry and politics were apparent all over the pages of the Press; and Clapp, a master of public relations if not of business management, learned early that printing a healthy dose of condemnation of his pet causes greatly helped bolster the presumed "objectivity" of his editing. He believed not only that any publicity was good publicity, but also that bad publicity served the dual purpose of 
additional exposure and the appearance of neutrality. So, two weeks after printing his adulatory review, Clapp printed two negative reviews of Leaves of Grass, one of which was perhaps the most scathingly cruel review Whitman would receive in his life.

The more tame of the two reviews was an untitled, anonymous reprint from the Albion and was comprised primarily of parodic "excerpts" from Leaves of Grass. Echoing many other reviews of Whitman's work, this one concluded that Whitman drew "a slender thread of truth and purity" through "a confused mass of folly, fecundity, and falsehood." The review is notable, though, for the ways in which its parodies characterize Whitman's views of African-Americans and women. Foreshadowing how Southern papers would soon characterize Whitman as the poet of abolition, the Albion review mocked Whitman's sense of aesthetics for finding beauty in Africans: "Of beauty. / Of excellence, of purity, of honesty, of truth. /Of the beauty of flat-nosed, pock-marked, pied Congo niggers!"

While the Albion review mocked Whitman, the other review in the June 2 Press was simply brutal. The piece, which the Press unfortunately misattributed to journalist and poet Juliette Beach, who was actually fond of Whitman's writing, ${ }^{12}$ concluded that Whitman could not even burn in hell because he lacked the soul to go there. Finally, the author recommended that Whitman kill himself:

If Walt has left within him any charity, will he not now rid the taught and disgusted world of himself? Not by poison, or the rope, or pistol, or by any of the common modes of suicide, because some full man, to whom life has become a grievous burden, may at a later day be compelled to choose between death by the same means and a hateful life, and with the pride of noble manhood turn shuddering to live on, rather than admit so much of oneness as would be implied by going to death as did Walt Whitman. But let him search the coast of his island home until he finds some cove where the waves are accustomed to cast up the carrion committed to them, and where their bloated bodies ride lazily upon the waters which humanity never disturbs, and casting himself therein find at last the companionship for which, in death as in life, he is best fitted.

The next week, among many other Whitman-related items, the Press published a correction, properly attributing the nasty review to Calvin Beach, Juliette's husband. Later that month, on June 23, Mrs. Beach would herself publish an adulatory review. However, she signed it simply "A Woman," though whether this was to offer a general, feminine defense of Whitman or to simply keep the peace at home-as she intimated later to Clapp-is unclear.

Controversy about Whitman had been brewing in the Press since his first appearance in its pages, and certainly the first Thayer and Eldridge advertisement to feature Whitman would have marked him as a factional 
poet. However, the June 9 issue of the Saturday Press would prove pivotal to securing Whitman's reputation as a distinctively Northern poet. The issue included five Whitman-related items, not counting advertisements. On the first page was Whitman's "Manahatta," the title of which, as will be explained later, was tellingly misspelled-in the Press it is given only one 'n,' whereas in the 1860 Leaves it has two ("Mannahatta"). In addition to an enigmatic parody titled "The Song of Dandelions (After Walt Whitman)" by the pseudonymous Babbaga Thabab, ${ }^{13}$ a correction explaining that Calvin Beach, not his wife, wrote the condemnatory article on Whitman in the previous week's issue, and an adulatory review by Mary Chilton, ${ }^{14}$ the Press also published a seemingly innocuous excerpt from Leaves titled "Longings from Home":

O magnet-South! O glistening, perfumed South! My South!

O quick mettle, rich blood, impulse, and love! Good and evil! O all dear to me!

$\mathrm{O}$ dear to me my birth-things-All moving things, and the trees where I was born-the grains, plants, rivers;

Dear to me my own slow sluggish rivers where they flow, distant, over flats of silvery sands, or through swamps, ... .

O pensive, far away wandering, I return with my Soul to haunt their banks again, ...

The piney odor and the gloom - the awful natural stillness, (Here in these dense swamps the freebooter carries his gun, and the fugitive slave has his concealed hut;)...

O my heart! O tender and fierce pangs-I can stand them not-I will depart;

$\mathrm{O}$ to be a Virginian, where I grew up! $\mathrm{O}$ to be a Carolinian!

O longings irrepressible! O I will go back to old Tennessee, and never wander more!

"Longings for Home" (eventually titled "O Magnet-South") has not been viewed as one of Whitman's great poems and has today settled into the background of Whitman scholarship. However, in 1860, the Northern newspaper's decision to print a poem by a Northern "bawd" claiming to be Southern was perhaps as controversial as any of its other Whitman-related articles. Surely this was aggravated by Whitmanthe seeming abolitionist-dropping a reference to runaway slaves. The following month, the Southern Literary Messenger - a fiercely regionalist publication that had, in these months before war, turned more and more to ideological content - included an editorial rant against Whitman that highlighted the Saturday Press's range of influence.

By this point, the Press had for several months been propping Whitman up-intentionally or not-as a Northern and distinctly partisan poet through its Thayer and Eldridge advertisements. M. Wynn Thomas has recently characterized "Longings for Home" as an example of Whitman's "conciliatory discourse" toward the South, the "poetical equivalent ... of his states' rights philosophy." 
Whitman intended the poem to assuage Southern readers, as Thomas convincingly argues, it failed. The editors of the Southern Literary Messenger, who had apparently followed Whitman's development in the Press, found this "conciliatory discourse" an unbearable insult. In the "Editor's Table," a collection of miscellany that included, among other things, an obituary for the "mad man" Theodore Parker, who had been frequently juxtaposed with Whitman in the Thayer and Eldridge advertisements, the editors reprinted "Longings for Home" with these comments preceding it:

The pantheism of Theodore Parker and Ralph Waldo Emerson, pervades and pollutes the entire literature of the North. It is nowhere more apparent than in that clumsy romance, "The Marble Faun." It culminates in the spasmodic idiocy of Walt Whitman. The smart scribblers who compose the better part of the Northern literati, are all becoming infected with the new leprosy-Whitmancy. This latest "representative man" of the North has his imitators by the hundred, admirers by the thousand, and an organ - the slang-whanging paper called The Saturday Press. A specimen of the twangling-jack style of Whitman is given below. Take a pair of frog-legs, put a tongue to every toe of both legs, and place the legs under a galvanic battery - and you have the utterings of Whitman. In the following slosh, Whitman says he "grew up" in Virginia. We should feel mean if this statement were anything else than a Whitmaniacal license, accent on the first vowel in license. Here is the sample of his obnubilate, incoherent, convulsive flub-drub.

Evidence of the Press's power in forging Whitman's reputation is scattered throughout this editorial-in its placing him alongside Parker and Emerson, just as the Press advertising does (though just how many of the Emerson ads, running that month, would have already made their way South is unclear), in its acknowledgement of his imitators and admirers, and in its explicit recognition that the Saturday Press is an "organ" for Whitman. ${ }^{16}$

The Saturday Press's influence on Southern opinions of Whitman is strikingly documented in one Southern paper, the New Orleans Sunday Delta, which was the weekly arts and letters issue of the New Orleans Delta. Within the span of one year, 1860, the Delta published four pieces by or about Whitman, all on the front page. The first, titled simply "Walt Whitman," included editorial commentary along with a reprinted Whitman poem ("Poemet") and an untitled parody. The article begins:

There is an unkempt, uncouth poet of New York, or rather of Brooklyn, whose name on earth, in common parlance, is Walt Whitman. The Cincinnati Commercial calls him the "Yahoo of American literature." Judging from specimens of his poetry, which we have seen, (his publishers have not sent the lately published volume of his "Leaves 
of Grass" to the South,) we think the Commercial scarcely does justice to his peculiar merits in calling him a Yahoo. We think rather that he can claim a comparison with the gorilla, one of the peculiarities of which is to pile up chunks of wood, in rude imitation of the house-building of his Ethiopian neighbors, but without having the slightest idea of making a house or any other rational object in view.

Besides adding "gorilla" to the list of insults cast at Whitman, the review is striking in its passing factionalizing of Whitman: the editors could as easily have written that Leaves had not yet arrived in Louisiana, or that it was difficult to find a copy of the book. Instead, they imply that the unnamed publishers have willfully withheld the book from the South, or that they had not dared to send it to the South - a reasonable implication considering that many sellers of abolitionist texts in the South were threatened with violence. ${ }^{17}$

Later in the same review, before reprinting "Poemet," the editors write, "That we may not be suspected of exaggerating Walt Whitman's oddities as a poet, we give the least rhapsodic and ragged, and least unintelligible of his compositions which we have seen. It appeared some time ago in the New York Saturday Press. ..." This review shows that Whitman was known to many Southern readers not through his book, but through the Press, in which his name and poems were framed by the factionalizing contexts of New York bohemianism and abolitionism.

The following week (June 24), the Delta ran an article titled "A Specimen from Walt Whitman," which claimed that "an alligator floundering in a slough, a hog wallowing in the mire, a buzzard plunging its beak into carrion . . . may all be lusty and natural, but not particularly sublime, beautiful, captivating, or even pleasant." The editors then offered their readers a selection "From Walt Whitman's 'Leaves of Grass," "Manahatta," with the same telltale typo-only one ' $n$ '- as the title had when it was printed in the Saturday Press two weeks earlier. The editors were still deriving their knowledge of Whitman from Clapp's paper.

A month later, on July 15, the Delta reprinted the parody "The TorchBearers" from, they claimed, Vanity Fair, though by that point it had already run in the Saturday Press, which may have been the Delta's true source. Interestingly, though, the Delta's derivations from the Saturday Press became reciprocated at about this time as the two papers commenced a somewhat dizzying swap of Whitman materials. On July 14, the Press excerpted the parody from the first (June 24) Whitman review in the Delta, which had itself derived from a poem published in the Press. Later, on November 11, the Delta published an original parody, "The City," that mockingly applied Whitman's style to a description of New Orleans, and this parody was in turn reprinted in the November 24 Saturday Press. Even as Southern editors were formulating a heavily partisan image of Whitman that was derived from his relationship with the Saturday Press, 
the Press was cannibalizing these formulations back into its own relentless and increasingly factional spotlighting of Whitman.

After the flurry of Whitman pieces in the June 9 issue that provoked such hostile Southern responses, the Press continued to feature pieces on Whitman, but with much less frequency after the end of the summer. "Walt Whitman and American Art," which is seldom discussed and is attributed to an anonymous author in Scott Giantvalley's Walt Whitman, 1838-1939, ${ }^{18}$ appeared in the June 30 issue and is almost certainly Clapp's work. The essay was printed, unsigned, on the editorial page, among several other unsigned miscellaneous pieces that all seem to be written by Clapp, and, in fact, loosely appear under his name, which is printed with the date as a header on the editorial column. Further, the style is effusively adulatory, as is so much of Clapp's writings on Whitman: "Into the company of poetasters, with their 'questionable, infirm paste-pots, ${ }^{19}$ paint-pots, varnish-pots, their putty, plaster, rouge, buckram - a miscellaneous theatrical property - walks, naked and stalwart, Walt Whitman, and all this trumpery seems to shrivel and melt away before his eyes." Clapp would write only one more article about Whitman for the Press before its closure in December, and that review would not appear for five more months. Clapp likely felt that the Press had accomplished its mission regarding Whitman, and that his participation was not much needed. From December 24, 1859, when Whitman's first poem appeared in the paper, through the end of June 1860, when Clapp published this article, over three-fourths of the essays and reviews published about Whitman in the Press were written specifically for that paper; afterward, only one-fifth were. So many other newspapers around the country and the world were printing articles-and parodies-on the poet that Clapp merely had to reprint them: parodies from Vanity Fair and the New Orleans Delta along with reviews from the Portland Transcript and London Leader in July; a review from the London Saturday Review, William Dean Howells's essay from the Ashtabula Sentinel, and a parody from the San Francisco Golden Era in August; and a review from the National Quarterly Review in September.

Clapp's last editorial about Whitman before the Press's closure in December commented, appropriately, on Whitman's supposed reception (the whole thing was actually a hoax) ${ }^{20}$ within the culture that had made Clapp a bohemian. The article, published on November 17, is comprised mostly of extracts from the preface to a nonexistent French translation of Leaves and of sample translations, making the editorial also the first published French translation of Whitman. ${ }^{21}$

The same issue of the Press was abuzz with the news that Clapp's paper was about to go under. In his typical style, Clapp reprinted several mentions of his failure from other newspapers, even those that were 
happy about its closure. The Sunday Atlas, in a reprinted piece called "Alas! Poor 'Saturday Press," blamed the paper's demise partially on its support of Whitman: "All the world does not admire bad imitations of the French journalists and feuilletonists; nor appreciate continual puffs of Walt Whitman's dirty 'Leaves of Grass' . . . [W] hen the epitaph of the SATURday PRess comes to be written. . . . That epitaph will read: 'Died of too much Bohemian twaddle.'”

Whitman's last appearance in this first run of the Saturday Press is nestled at the bottom of the last page of the last issue. Titled simply "A Portrait," the poem is an excerpt (consisting of stanzas 6-9) of what was "Enfans d'Adam" \#3 in 1860, which would eventually become part of "I Sing the Body Electric." Recently, Kenneth M. Price has pointed out the racial ambiguity of this passage, which describes a "common farmer" with "black eyes," "clear-brown skin," and "tan-faced" sons. Price suggests that this ambiguity strengthens Whitman's question: "Who might you find you have come from yourself if you could trace back through the centuries?" (19) The publication of the passage as a stand-alone, titled poem in the Saturday Press adds to it yet another incarnation. While its racial ambiguities may be more striking within the larger context of Leaves of Grass - where it circulated in many forms over the years - its periodical context lent to it a resonance that gets lost in the longer work. On the eve of war, with the paper of his friend and supporter in its last throes, Whitman's final lines impart a message of camaraderie and hope:

I have perceived that to be with those I like is enough,

To stop in company with the rest at evening is enough,

To be surrounded by beautiful, curious, breathing, laughing flesh is enough,

To pass among them, or touch any one, or rest my arm ever so lightly round his or her neck for a moment-what is this, then?

I do not ask any more delight-I swim in it, as in a sea.

There is something in staying close to men and women, and looking on them, and in the contact and odor of them, that pleases the soul well;

All things please the soul—but these please the soul well.

Five years later, in August of 1865, Clapp published the first issue of the new series of the Press, though this second incarnation was doomed from the start. Clapp, who had pieced together a living as a writer during the War, was still an inept businessman, and now the momentum behind antebellum bohemianism had petered out. Some of the most renowned New York bohemians had died; others had moved on, including Whitman, whose war experiences irrevocably shifted the course of his life. Clapp lacked the business savvy and the community for his paper to endure. 
In the five-year hiatus between the end of the Press's first run and the beginning of the second, Whitman and Clapp became somewhat estranged. The reasons are not entirely clear-Whitman thought fondly of Clapp until the end of his life, and the appearance of some Whitman materials in the second run indicate that Clapp had not altogether soured on Whitman. Likely the sheer enormity of the war and the men's contrasting responses to it distanced them. Indeed, it is difficult to imagine the war nurse, who moved to Washington and threw himself into his work for the injured, finding much common ground with the New Yorker who maintained his geographic remove and biting sarcasm through the tragedy. Nonetheless, the two men again collaborated, however briefly, in bringing public attention to Whitman's poetry. In the ten months of the Press's second run, Clapp would publish two pieces by or about Whitman: first, Whitman's “O Captain! My Captain!” and then a review of Drum-Taps.

When read within Leaves of Grass, the conventional aesthetics of "O Captain!" strike many contemporary readers as a blemish on the aesthetic of the rest of the book. Whitman did not originally publish "O Captain!" in Leaves of Grass, though, but instead published it in the Press just as he was releasing Drum-Taps and Sequel to Drum-Taps, which contained the poem. In keeping with Whitman's history of clever public relations maneuvers, the poem essentially functioned as a "teaser," however misleading, for Drum-Taps.

Earlier in 1865, Whitman had begun publishing this collection of war verse, but had postponed publication after Lincoln's assassination until he had time to incorporate a sequel honoring the president. By this time, Whitman's readership was overshadowed by his notoriety, gained through numerous public accusations and refutations of obscenity, including his recent dismissal from the Indian Bureau on such charges. A few months later, when Whitman published "O Captain!" in the Saturday Press, it was possibly his business sense more than his poetics that inspired him to give a Northern, mourning audience-skeptical of him but eager to make sense of the tumult around them-a poem that they would find ideologically and aesthetically satisfactory. As with Whitman's and Clapp's earlier dealings, the publication of "O Captain!" was mutually beneficial: the inclusion of a poem by a famous and controversial poet would attract readers to the Press; their finding that the poem was conventional would attract them to Whitman's book.

Whitman's intentions to redeem his reputation with "O Captain!" are apparent in a manuscript draft held in the Library of Congress (see Figure 7). ${ }^{22}$ Ed Folsom has pointed out that Whitman sometimes turned to conventional poetics during times of political upheaval, as with his "Ethiopia Saluting the Colors," 23 but it seems that this turn was not 


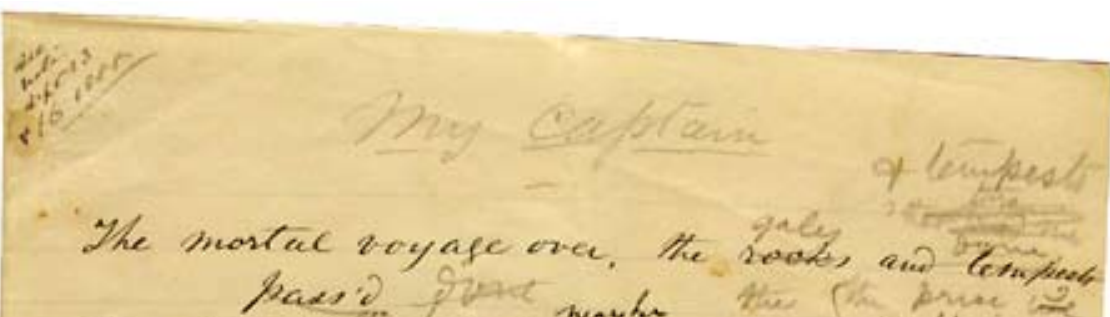

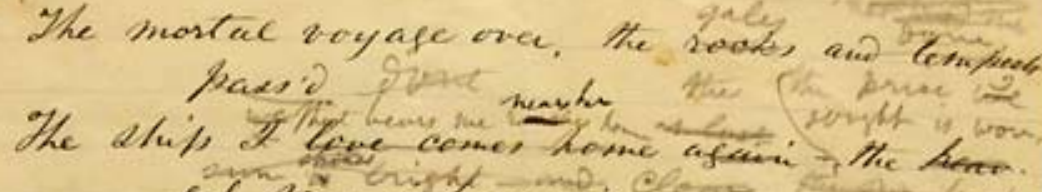
ans dian "Litameys:

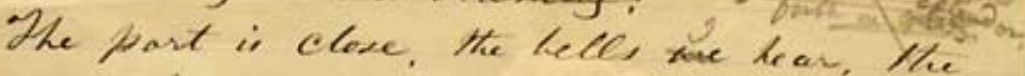
As people all exalt...

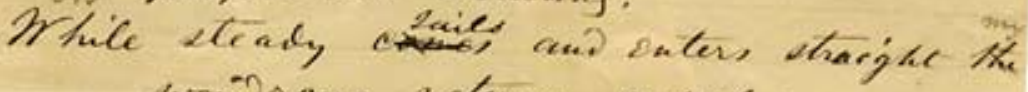
wow ion teleran resell:

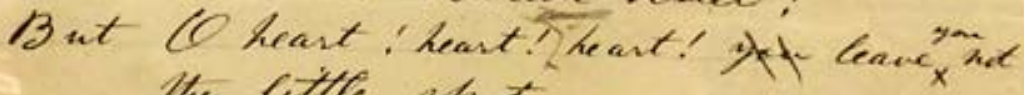
the little spot.

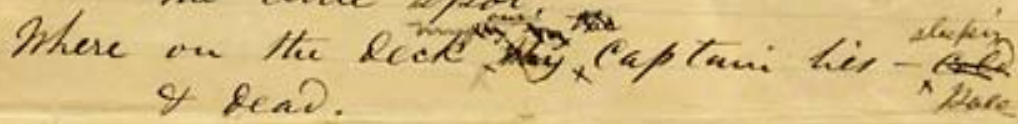

10 cetane.' decree captain: we the up ot hear the bell,

Nader up of see the Stinging true, of see the

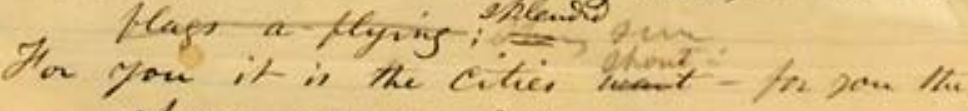
clares are crowded?

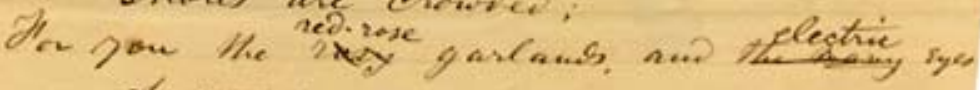
of warren?

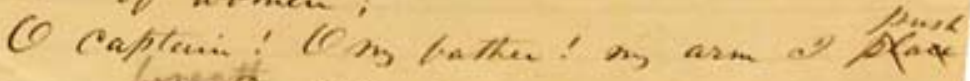

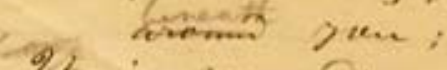

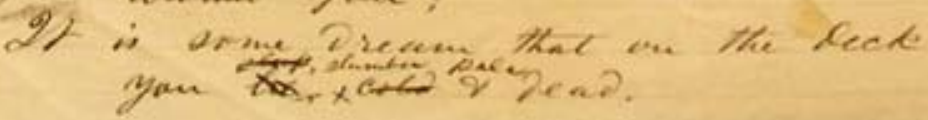

Figure 7. "My Captain." The Charles E. Feinberg Collection of the Papers of Walt Whitman, 1839-1919, Library of Congress, Washington, D.C.

162 
at all automatic, and in this case Whitman seemed to be deliberately making a salve for his ailing country and, more practically, for his ailing finances. This early draft, written sometime between Lincoln's assassination in April and the publication of "O Captain!" in October, shows Whitman's intention to write the poem in unrhymed verse. He drafted the poem first in ink, with no end-rhymes. Later, he revised this draft with a pencil and began sketching out the rhyme scheme that he would fully implement in the published version.

If it was, in fact, Whitman's intention to redeem his reputation and drum up a wider audience for his poetry through the publication of the conventional "O Captain!," his plan worked. Three months after its appearance in the Saturday Press, a reviewer for the Boston Commonwealth wrote, "this displaced and slighted poet has written the most touching dirge for Abraham Lincoln of all that have appeared" before quoting it in its entirety. "O Captain! My Captain!" soon became Whitman's most anthologized poem and perhaps his most famous poem, much to Whitman's chagrin. In 1889, he told Traubel, "It's My Captain again: always My Captain: the school readers have got along as far as that! My God! When will they listen to me for whole and good?" (WWC 4:393). The difference in the reception of Whitman's pre-War offering of conciliatory imagination, "Longings for Home," and the post-War publication of "O Captain!" are striking. Both were enabled by Clapp in the pages of the Saturday Press, but "O Captain!"-for all its aesthetic deficiencies-shows how the intervening years matured Whitman's understanding of his role as a public poet.

The Press closed permanently in June of 1866, the conclusion of a career that Whitman later summarized as "Henry's heroic struggle, how he went confidently on in spite of reverses: how finally he was backed to the wall and slaughtered" (WWC 4:196). Clapp died in 1875 after years of alcoholic decline. Decades after Whitman's last dealings with the Press, he reflected on his lifelong dealings with editors: "The truth is, what for editorial hard blows, I haven't got a whole bone left in my body. . . . But what's the use of diagnosing over cured diseases? I think I have finally escaped the hounds and can go the rest of the way in comparative peace" ( $W W C 1: 264)$. As Whitman knew, it was in fact an editor that helped him escape those hounds, even if he had set them on Whitman to begin with. Months later, Whitman told Traubel, "Henry was my friend: he would have done anything for me: . . first of all he said he wished me to have a fair show: 'With half a fair show, Walt,' he used to say, 'I know you can take care of yourself' (WWC 4:196).

\section{University of Georgia}




\section{NOTES}

I thank Kenneth M. Price, Susan Belasco, and Leo Iacono for their very helpful comments on this article.

1 Whitman, Leaves of Grass (Brooklyn, NY: n.p., 1856), 194; available online at the Walt Whitman Archive (www.whitmanarchive.org/published/LG/index.html).

2 Horace Traubel, With Walt Whitman in Camden, 9 vols. (various publishers, 1906-1996; online at http://www.whitmanarchive.org/disciples/index.html), 1:237; hereafter $W W C$.

3 Recently, David Haven Blake (Walt Whitman and the Culture of American Celebrity [New Haven: Yale University Press, 2006]) has argued that, while Pfaff's bohemian circle did provide Whitman with a community, Whitman found the group's status as a subculture disconcerting. Blake writes, "At a time when others were downright hostile to his work, the writers at Pfaff's considered the poet to be among the age's most significant writers. For Whitman, though, such backing was not enough ..." (61). Readers broadly interested in writings by the Pfaff's circle should consult the new digital project The Vault at Pfaff's, online at digital.lib.lehigh.edu/pfaffs/.

4 David Reynolds, Walt Whitman's America: A Cultural Biography (New York: Knopf, 1995), 378.

5 The Press, constantly plagued by financial instability, had two incarnations: the first ran from October 23, 1858, to December 15, 1860; the second from August 5, 1865, to June 2, 1866.

6 A complete list and the transcriptions of poems that Whitman published in the Saturday Press is available online at the Walt Whitman Archive (www.whitmanarchive. org/published/periodical/index.html).

7 After this essay was accepted for publication I discovered that Ted Genoways's recent doctoral dissertation (Whitman's Lost War: America's Poet during the Forgotten Years of 1860-1862 [University of Iowa, 2007]) independently pursues a very similar analysis of the relationship among Whitman, Clapp, and Thayer and Eldridge. Readers interested in this topic, especially in Thayer and Eldridge's connections to abolition, would be well advised to read this dissertation.

8 Albert J. Von Frank, "The Secret World of Radical Publishers: The Case of Thayer and Eldridge of Boston," in James M. O'Toole and David Quigley, eds., Boston's Histories (Boston: Northeastern University Press, 2004), 52-70.

9 Leaves as a text was very much still in flux at this time. Just a month earlier Whitman published a single poem titled "Leaves" in the Saturday Press, which he divided and distributed into "Calamus" \#21, "Calamus" \#37, and "Enfans d'Adam" \#15 in the new edition.

10 Ezra Greenspan, Walt Whitman and the American Reader (New York: Cambridge University Press, 1990), 210-212.

11 See Genoways, Whitman's Lost War.

12 On April 7, Juliette Beach published a review of Harriet Prescott's Amber Gods in the Press in which she favorably likened Prescott's style to Whitman's: 
Imagine this book to have been the creation of Tennyson, with his exquisite rhythm; or of Walt Whitman, with his grand simplicity of expression and Eastern style. The idea is ravishing.

I have amused myself fancying some of its finest passages in the manner of the latter poet, and here is one:

The three graves, the long slope, and the sea behind;

And before,- - between the gaps of the cliffs reddening with morning;-

The cross-roads, and a sunrise boiling wildly

Athwart low inland plains. ...

13 No plausible theory for Babbaga Thabab's identity has been put forward.

14 Chilton was a well-known feminist and free-love advocate whose name would have contributed notably to the controversy surrounding Leaves of Grass. Chilton's review helped make visible bohemian support for Whitman's volume, and probably was meaningful to Whitman, since evidence suggests that Chilton's writings on sexual freedom were influential to him. For a more detailed explanation of both Whitman's relationship to Chilton's work and the Juliette/Calvin Beach fiasco, see Sherry Ceniza, “'Being a Woman . . . I Wish to Give My Own View': Some Nineteenth-Century Women's Responses to the 1860 Leaves of Grass" in The Cambridge Companion to Walt Whitman, ed. Ezra Greenspan (Cambridge: Cambridge University Press, 1995), 110-134.

15 M. Wynn Thomas, Transatlantic Connections: Whitman U.S., Whitman U.K. (Iowa City: University of Iowa Press, 2005), 101.

16 Interestingly, the page that contains this editorial also includes two other pieces: the first is a sign written by a functionally illiterate black shoe-shiner, recreated by a reader who sent it in for the purpose of mocking the man's illiteracy. The second is an anecdote recounting a white reader's conversation with some Native Americans at a black man's hanging, in which the Native Americans ignorantly (and to the amusement of the contributor) confuse the governor of Virginia with the President of the United States. This context for the Messenger's reprinting of "Longings for Home" is important in that it powerfully illustrates not only how this Southern magazine was reinforcing notions of white Southern supremacy by mocking the voices of the "other," but also indicates that on the eve of the Civil War, Whitman was viewed by the South as just such an "other." This provides an excellent example of how some nineteenth-century critics, as Kenneth $M$. Price has put it, "made [Whitman], as it were, black," and "an outsider in his own land." Ironically, Whitman's "Longings for Home," which may have been intended as an overture of inclusion, of a Northern poet's embrace of a Southern identity, became a mechanism of factionalizing Whitman through his association with the Press. See Kenneth M. Price, To Walt Whitman, America (Chapel Hill: University of North Carolina Press, 2004), 10.

17 See Genoways, Whitman's Lost War.

18 Scott Giantvalley, Walt Whitman, 1838-1939: A Reference Guide (Boston: G. K. Hall, 1981), 14.

19 The origin of the "paste-pot" image is in Carlyle's Past and Present (Book 3, Chapter 15): "the numerous long placard-poles, and questionable infirm paste-pots, interfering with one's peaceable thoroughfare sometimes!" Whitman echoes Carlyle and Clapp later in Democratic Vistas: "Do you call those genteel little creatures American poets? Do you term that perpetual, pistareen, paste-pot work, American art, American drama, taste, verse?" (Prose Works 1892, ed. Floyd Stovall [New York: New York University Press, 1964], 2:388-389). 
20 The entire article was a hoax, though whether Clapp was the orchestrator of the hoax or an unwitting pawn in someone's practical joke is a matter of critical debate. See Ezra Greenspan, "The Earliest French Review of Walt Whitman," Walt Whitman Quarterly Reivew 6 (Winter 1989), 109-116; and "More Light on the Earliest French Review of Whitman," Walt Whitman Quarterly Review 8 (Summer 1990), 45-46; and Roger Asselineau, "The Earliest French Review of Whitman (Continued),"Walt Whitman Quarterly Review 8 (Summer 1990), 47-48.

21 The first review of Whitman in France was by Louis Etienne and was published in November of 1861.

22 I thank Andrew Jewell for calling my attention to this manuscript.

23 Ed Folsom, "Lucifer and Ethiopia: Whitman, Race, and Poetics before the Civil War and After" in David S. Reynolds, ed., A Historical Guide to Walt Whitman (New York: Oxford University Press, 2000), 54. 